\title{
A novel role for GSK3 in the regulation of the processes of human labour
}

\author{
Ratana $\operatorname{Lim}^{1,2}$ and Martha Lappas ${ }^{1,2}$ \\ ${ }^{1}$ Mercy Perinatal Research Centre, Mercy Hospital for Women, Heidelberg, Victoria, Australia and ${ }^{2}$ Obstetrics, \\ Nutrition and Endocrinology Group, Department of Obstetrics and Gynaecology, University of Melbourne, \\ Level 4/163 Studley Road, Heidelberg, Victoria 3084, Australia
}

Correspondence should be addressed to M Lappas; Email: mlappas@unimelb.edu.au

\begin{abstract}
Preterm birth remains the largest single cause of neonatal death and morbidity. Infection and/or inflammation are strongly associated with preterm delivery. Glycogen synthase kinase 3 (GSK3) is known to be a crucial mediator of inflammation homeostasis. The aims of this study were to determine the effect of spontaneous human labour in foetal membranes and myometrium on GSK3 $\alpha / \beta$ expression, and the effect of inhibition of GSK3 $\alpha / \beta$ on pro-labour mediators in foetal membranes and myometrium stimulated with Toll-like receptor (TLR) ligands and pro-inflammatory cytokines. Term and preterm labour in foetal membranes was associated with significantly decreased serine phosphorylated GSK3 $\alpha$ and $\beta$ expression, and thus increased GSK3 activity. There was no effect of term labour on serine phosphorylated GSK3 $\beta$ expression in myometrium. The specific GSK3 $\alpha / \beta$ inhibitor CHIR99021 significantly decreased lipopolysaccharide (ligand to TLR4)-stimulated pro-inflammatory cytokine gene expression and release; COX2 gene expression and prostaglandin release; and MMP9 gene expression and pro MMP9 release in foetal membranes and/or myometrium. CHIR99021 also decreased FSL1 (TLR2 ligand) and flagellin (TLR5 ligand)-induced pro-inflammatory cytokine gene expression and release and COX2 mRNA expression and prostaglandin release. GSK3 $\beta$ siRNA knockdown in primary myometrial cells was associated with a significant decrease in IL1 $\beta$ and TNF $\alpha$-induced pro-inflammatory cytokine and prostaglandin release. In conclusion, GSK3 $\alpha / \beta$ activity is increased in foetal membranes after term and preterm labour. Pharmacological blockade of the kinase GSK3 markedly reduced pro-inflammatory and pro-labour mediators in human foetal membranes and myometrium, providing a possible therapeutics for the management of preterm labour. Reproduction (2015) 149 189-202
\end{abstract}

\section{Introduction}

Preterm birth is the prevalent cause of mortality and morbidity in newborn infants (McCormick 1985). Potential complications that can arise include neonatal sepsis and foetal respiratory distress (Lawn et al. 2005). The survivors of preterm birth also have increased risk of neurodevelopmental impairments and gastrointestinal and respiratory complications (Goldenberg et al. 2008). While $\sim 30 \%$ of preterm deliveries are iatrogenic, $70 \%$ of preterm deliveries are spontaneous, relating to preterm labour or preterm rupture of the membranes (Goldenberg et al. 2008). As there are no effective methods of prediction or prevention (Norman \& Shennan 2013), it is essential that our understanding of the mechanisms involved in the initiation and progression of labour is improved in order to develop therapeutics.

For the successful culmination of labour and delivery, foetal maturation, cervical ripening and dilatation, uterine contractions and foetal membrane rupture are necessary. These events are potentiated by the production of inflammatory mediators, such as pro-inflammatory cytokines, phospholipid metabolites, including prostaglandins, and extracellular matrix remodelling enzymes, such as matrix metalloproteinase 9 (MMP; Bowen et al. 2002, Olson 2003, Lappas \& Rice 2004, Weiss et al. 2007, Christiaens et al. 2008). Preterm birth may occur due to the untimely activation of these processes, regardless of foetal development. Toll-like receptors (TLRs) are key surface molecules that play an essential role in triggering the immune response. The bacterial products which are ligands to TLRs, including the synthetic lipoprotein fibroblast-stimulating lipopeptide (FSL1; TLR2 ligand), lipopolysaccharide (LPS; TLR4 ligand) and flagellin (TLR5 ligand) are known to produce an inflammatory response in human gestational tissues (Lappas et al. 2006, Lim et al. 2014a). To develop therapeutics to stop or delay preterm labour, a greater understanding of the multiple processes that are involved in human parturition is required.

Recent studies have pointed to the pleiotropic serine threonine kinase glycogen synthase kinase 3 (GSK3) as a crucial mediator of inflammation homeostasis (Jope \& Johnson 2004, Jope et al. 2007, Beurel et al. 2010). 
In mammals, GSK3 exists as two isoforms: GSK3 $\alpha$ and $\beta$ which are structurally similar but encoded by distinct genes and have molecular weights of 51 and $47 \mathrm{kDa}$ respectively (Woodgett 1990). Although the two isoforms of GSK have similar functions, they are not functionally redundant as deletion of GSK3 $\beta$ leads to embryonic lethality at E16 that cannot be rescued by GSKa (Hoeflich et al. 2000). Originally involved in insulin signalling (Woodgett 1990), GSK3, particularly GSK3 $\beta$, has now been shown to be essential for a number of critical cellular functions, such as cell cycle control, apoptosis, embryonic development, cell differentiation and adhesion (Frame \& Cohen 2001, Grimes \& Jope 2001, Doble \& Woodgett 2003, Jope \& Johnson 2004, Wang et al. 2011a). As such, GSK3 has been implicated in a number of diseases, including type 2 diabetes, cancer and a number of inflammatory diseases (Jope et al. 2007, Gurrieri et al. 2010), with GSK inhibitors being actively developed as therapeutics for the treatment of these various disorders.

In vitro, GSK3 $\alpha / \beta$ inhibition has been shown to suppress inflammation in response to a variety of stimuli such as tumor necrosis factor alpha (TNF $\alpha$ ), interleukin 1 beta (IL1 $\beta$ ), bacterial endotoxin LPS and cigarette smoke (Takada et al. 2004, Martin et al. 2005, Barton-Pai et al.

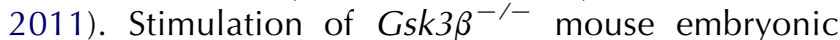
fibroblast with LPS (Martin et al. 2005) or TNF $\alpha$ (Steinbrecher et al. 2005) was associated with a reduction in the production of pro-inflammatory cytokines. Of note, inhibitors of GSK3 have been reported to exert beneficial effects in many different, preclinical animal models of disease. Mice treated with GSK3 inhibitors are protected from LPS-induced septic shock (Martin et al. 2005) and have increased survival rates to Francisella tularensis infection (Zhang et al. 2009). In addition, GSK3 inhibitors reduce inflammation and tissue injury in a rat model of acute colitis (Whittle et al. 2006).

A number of mechanisms have been identified that contribute to regulating the actions of GSK3 (Grimes \& Jope 2001). The most well-defined regulatory mechanism is inhibition of the activity of GSK3 by phosphorylation of a regulatory serine in either of the two isoforms of GSK3, Ser9 in GSK3 $\beta$ or Ser21 in GSK3 $\alpha$ (Woodgett 1990). To our knowledge, the expression or the role of GSK3 $\alpha / \beta$ has not been investigated in human foetal membranes and myometrium. We hypothesised that human labour and delivery would be associated with decreased phosphorylated GSK3 $\alpha / \beta$, and thus increased GSK3 activity, in foetal membranes and myometrium. In addition, we hypothesised that inhibition of GSK3, using a chemical inhibitor or siRNA, would be associated with decreased expression and secretion of pro-labour mediators in the presence of bacterial infection or pro-inflammatory cytokines. Thus, the aims of this study were i) to establish the effect of human labour on phosphorylated GSK $3 \alpha / \beta$ expression in human foetal membranes and myometrium and ii) to determine the effect of inhibition of GSK3 $\alpha / \beta$ on LPS, flagellin and FSL1-induced expression of pro-inflammatory and pro-labour mediators in human foetal membranes and myometrium.

\section{Materials and methods}

\section{Tissue collection}

The Research Ethics Committee of Mercy Hospital for Women approved this study. Informed written consent was obtained from all participating women. All tissues were obtained from women who delivered healthy, singleton infants. All tissues were brought to the research laboratory and processed within $15 \mathrm{~min}$ of delivery. Women with any underlying medical conditions such as diabetes, asthma, polycystic ovarian syndrome, preeclampsia and macrovascular complications were excluded. In addition, women with multiple pregnancies, obese women, foetuses with chromosomal abnormalities were excluded.

Foetal membranes were obtained from women i) at term no labour undergoing elective Caesarean section (indications for Caesarean section were breech presentation and/or previous Caesarean section; $n=8$ patients) and ii) term after spontaneous labour, spontaneous membrane rupture and normal vaginal delivery ( $n=8$ patients). The foetal membranes were obtained $\sim 2 \mathrm{~cm}$ from the periplacental edge. Clinical details of the patients are detailed elsewhere (Lappas et al. 2011). There was no difference in maternal age and BMI, parity or gestational age of the patients recruited. The mean duration of labour was $6.5 \pm 0.7 \mathrm{~h}$. The tissue samples were snap frozen in liquid nitrogen and immediately stored at $-80{ }^{\circ} \mathrm{C}$ for the analysis of phosphorylated GSK $3 \alpha / \beta$ protein expression by western blotting.

The foetal membranes were also obtained from women at i) preterm no labour undergoing Caesarean section $(n=8$ patients) and ii) after spontaneous preterm labour and normal vaginal delivery ( $n=8$ patients). All placentas collected at preterm gestations were swabbed for microbiological culture investigations and histopathological examination. The patients with chorioamnionitis were excluded from the analyses. Women with preeclampsia, preexisting diabetes, asthma, multiple pregnancies and foetuses with chromosomal abnormalities were also excluded. Indications for preterm delivery (in the absence of labour) were placenta praevia, placental abruption, antepartum haemorrhage (APH) or Rhesus isoimmunisation. For the preterm labour study, foetal membranes from both the non-labouring and after-labour preterm groups were obtained $2 \mathrm{~cm}$ from the periplacental edge. Clinical details of the patients are detailed elsewhere (Lim et al. 2013a). The tissue samples were snap frozen in liquid nitrogen and immediately stored at $-80{ }^{\circ} \mathrm{C}$ for the analysis of phosphorylated GSK3 $\alpha / \beta$ expression by western blotting.

Myometrium was obtained from consenting women at the time of term Caesarean section ( $\geq 37$ weeks' gestation). Myometrial biopsies were collected from two groups of women: i) no labour-pregnant women undergoing elective Caesarean section in the absence of labour ( $n=8$ patients) and ii) in labour-pregnant women who were delivered during active labour (labour was defined as the presence of regular uterine contractions (every 3-4 min) resulting in cervical effacement 
and dilation) ( $n=8$ patients). Women were excluded from the study if they had a multiple pregnancy or evidence of an active infection. A myometrial biopsy was obtained from the upper margin of the lower uterine segment incision during the Caesarean section. Tissue samples snap frozen in liquid nitrogen and immediately stored at $-80{ }^{\circ} \mathrm{C}$ for the analysis of phosphorylated GSK $3 \alpha / \beta$ protein expression by western blotting.

\section{Tissue explant culture}

Tissue explants were performed as described previously (Lappas 2013, Lim et al. 2014a) to determine the effect of the GSK3 $\alpha / \beta$ inhibitor CHIR99021 on pro-inflammatory and pro-labour mediators in foetal membranes and myometrium. Fresh foetal membranes and myometrium were obtained from women who delivered healthy, singleton infants at term (37-41 weeks gestation) undergoing elective Caesarean section in the absence of labour. The tissues were placed in DMEM at $37{ }^{\circ} \mathrm{C}$ in a humidified atmosphere of $8 \% \mathrm{O}_{2}$ (foetal membranes) or $21 \% \mathrm{O}_{2}$ (myometrium) and $5 \% \mathrm{CO}_{2}$ for $1 \mathrm{~h}$. The tissues were blotted dry on sterile filter paper and transferred to 24-well tissue culture plates (100 mg wet weight/well for foetal membranes and $50 \mathrm{mg}$ wet weight/well for myometrium). The explants were incubated in $1 \mathrm{ml}$ DMEM containing $100 \mathrm{U} / \mathrm{ml}$ penicillin $\mathrm{G}$ and $100 \mu \mathrm{g} / \mathrm{ml}$ streptomycin. The tissues were incubated in the presence of $10 \mu \mathrm{M}$ CHIR99021 (Sapphire Bioscience, Waterloo, NSW, Australia) with $10 \mu \mathrm{g} / \mathrm{ml}$ LPS (derived from Escherichia coli 026:B6; Sigma-Aldrich), 250 ng/ml FSL1 (Life Research, Scoresby, VIC, Australia) and $1 \mu \mathrm{g} / \mathrm{ml}$ flagellin (Life Research) for $20 \mathrm{~h}$. CHIR99021 was dissolved in dimethylsulfoxide (DMSO); thus, all treatments contained DMSO at a final concentration of $0.05 \% \mathrm{vol} / \mathrm{vol}$. The concentration of CHIR99021 was based on past studies (Wang et al. 2011b, Balamurugan et al. 2013) and the bacterial products were based on our previously published studies (Lappas 2013, Lim et al. 2014a). After incubation, tissue and media were collected separately and stored at $-80{ }^{\circ} \mathrm{C}$ for further analysis as detailed below. Experiments were performed on myometrium and foetal membranes from six patients.

In this study, we used the GSK3 $\alpha / \beta$ inhibitor CHIR99021, an aminopyrimidine which is the most selective inhibitor of GSK $3 \alpha / \beta$ reported to date, exhibiting $>500$-fold selectivity for GSK3 over closely related kinases, and is thought to inactivate the phosphorylative ability of GSK3 (Ring et al. 2003). We also used siRNA, targeted specifically against GSK3 $\beta$; the $\beta$ isoform is known to be involved in inflammation (Martin et al. 2005, Adams-Chapman \& Stoll 2006, Barton-Pai et al. 2011).

To determine the effect of treatment on cell membrane integrity, the release of the intracellular enzyme lactate dehydrogenase (LDH) into incubation medium was determined as described previously (Lim et al. 2013b). Neither in vitro incubation nor experimental treatment significantly affected LDH activity in the incubation medium (data not shown).

\section{Gene silencing of GSK3 $\beta$ with siRNA}

Primary myometrial cells were used to investigate the effect of siRNA-mediated gene silencing of $G S K 3 \beta$ on pro-labour mediators. Myometrium was obtained from women who delivered healthy, singleton infants at term (37-41 weeks gestation), undergoing elective Caesarean section in the absence of labour. The cells were isolated and cultured as described previously for myometrium (Lappas 2013, Lim et al. $2013 \mathrm{~b}$ ). The cells at $\sim 50 \%$ confluence were transfected using SilenceMag reagent according to the manufacturer's guidelines (Oz Biosciences, Marseille, France) and as described previously (Lim et al. 2013a,b). GSK3 $\beta$ siRNA (HSC.RNAI. N001146156.12) was obtained from Integrated DNA Technologies (IDT, Coralville, IA, USA), while negative control (NC) siRNA was obtained from Sigma-Aldrich. The cells were transfected with $200 \mathrm{nM}$ GSK3 $\beta$ or $200 \mathrm{nM} \mathrm{NC}$ siRNA in DMEM/F-12 for $48 \mathrm{~h}$. The medium was then replaced with DMEM/F-12 with or without $1 \mathrm{ng} / \mathrm{ml}$ IL $1 \beta$ or $10 \mathrm{ng} / \mathrm{ml} \mathrm{TNF} \alpha$, and the cells were incubated at $37^{\circ} \mathrm{C}$ for an additional $24 \mathrm{~h}$. The cells were collected and stored at $-80^{\circ} \mathrm{C}$ until assayed for mRNA expression by quantitative RT-PCR (qRT-PCR) and protein expression by western blotting as detailed below. Media was collected and stored at $-80^{\circ} \mathrm{C}$ until assayed for cytokine release as detailed below. The cell viability was assessed by the 3-(4,5-dimethyl-2-thiazolyl)-2,5-diphenyl-2 $\mathrm{H}$ tetrazolium bromide (MTT) proliferation assay as described previously (Lim et al. 2014b). The experiments were carried out in the myometrium obtained from five patients.

\section{Western blotting}

The tissue lysates and western blotting were prepared as described previously (Lappas et al. 2011). In brief, $30 \mathrm{mg}$ protein were separated on polyacrylamide gels (Bio-Rad Laboratories) and transferred onto PVDF. Protein expression was identified by comparison with the mobility of protein standard. The membranes were viewed and analysed using the ChemiDoc XRS System (Bio-Rad Laboratories). Semiquantitative analysis of the relative density of the bands in western blottings was performed using Quantity One 4.2.1 image analysis software (Bio-Rad Laboratories). For Fig. 1, the levels of phosphorylated GSK3 $\alpha / \beta$ (1:1000; \#9331, Cell Signalling, Beverly, MA, USA) were normalised to the levels of total GSK3 $\beta$ (1:1000; \#9315, Cell Signalling); fold change was calculated relative to the no-labour group. For Fig. $8 \mathrm{~A}$, the levels of total GSK3 $\beta$ (1:1000; \#9315, Cell Signalling) were normalised to the levels of $\beta$-actin.

\section{RNA extraction and $q R T-P C R$}

Total RNA was extracted from tissues using TRIsure reagent according to manufacturer's instructions (Bioline, Alexandria, NSW, Australia), as previously described (Lim et al. 2013a,b). RNA concentration and purity were measured using a NanoDrop ND1000 Spectrophotometer (Thermo Fisher Scientific, Waltham, MA, USA). RNA was converted to cDNA using the Tetro cDNA Synthesis Kit (Bioline) according to the manufacturer's instructions. The cDNA was diluted to 50 -fold, and $4 \mu \mathrm{l}$ of this was used to perform RT-PCR using the Sensimix Plus SYBR Green (Bioline) and $200 \mathrm{nM}$ of pre-designed and validated QuantiTect Primers (Qiagen). The RT-PCR was performed using a CFX384 Real-Time PCR 

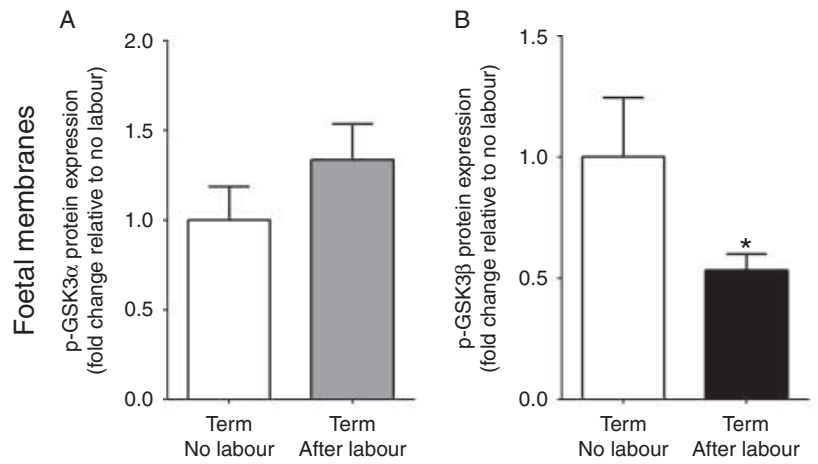

C
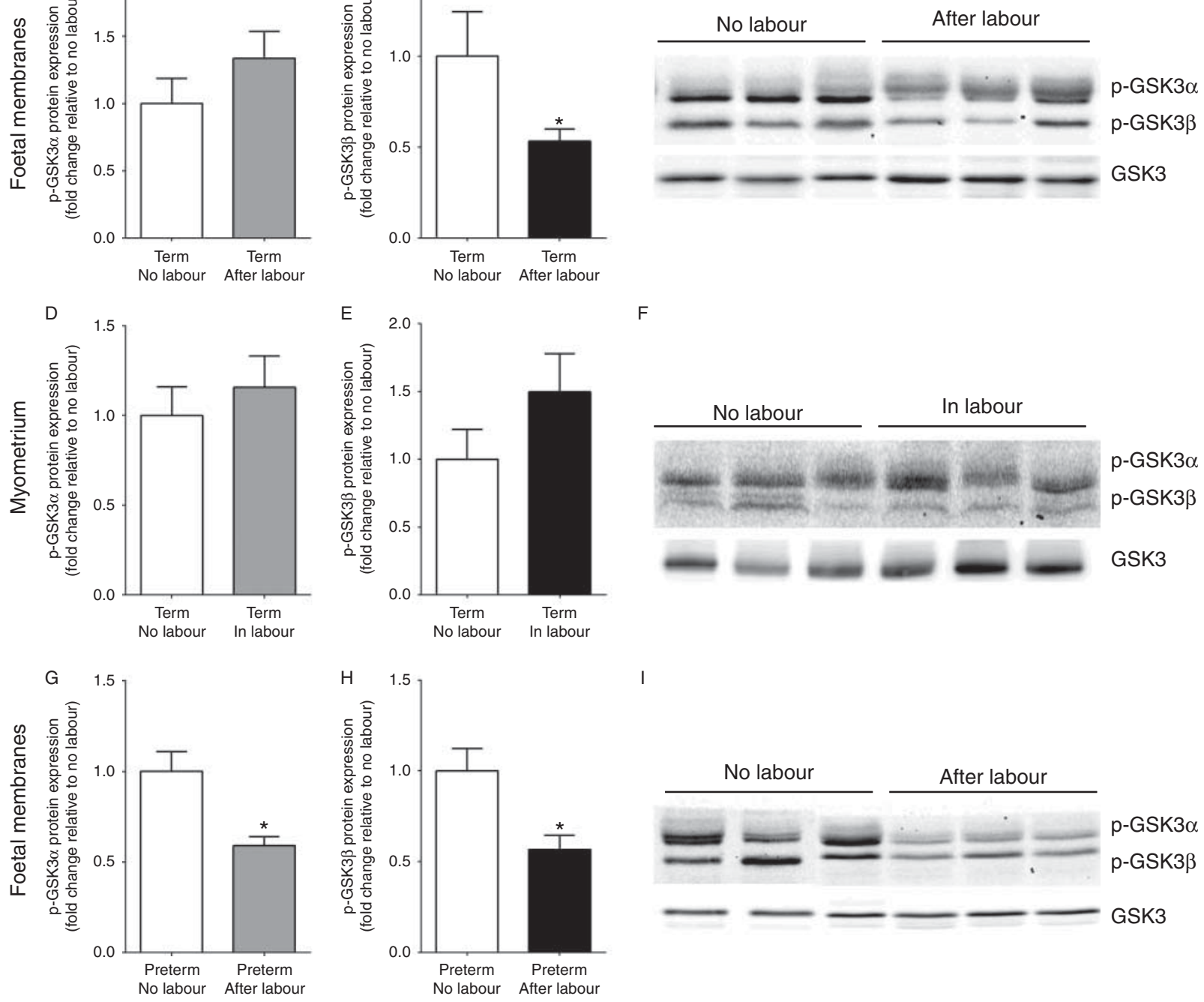

I

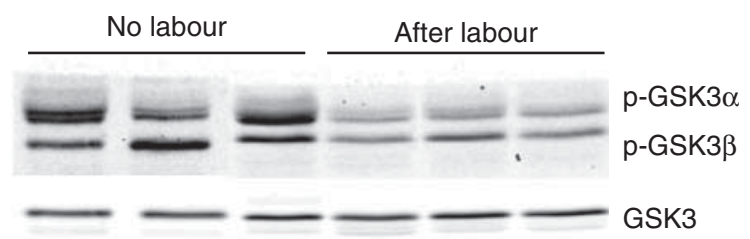

Figure 1 Effect of human labour on phosphorylated GSK3 $\alpha / \beta$ expression in foetal membranes and myometrium. (A, B and C) Human foetal membranes were obtained from women not in labour at term Caesarean section and women after term spontaneous labour onset and delivery $(n=8$ patients/group). (D, E and F) Human myometrium was obtained from non-labouring and labouring women at term Caesarean section ( $n=8$ patients/group). (G, H and I) Human foetal membranes were obtained from women not in labour at preterm Caesarean section and women after preterm spontaneous labour onset and delivery ( $n=8$ patients/group). Phosphorylation of GSK3 $\alpha$ at serine 21 (51 kDa) and GSK3 $\beta$ at serine 9 ( $47 \mathrm{kDa}$ ) was analysed by immunoblotting with GSK3 phospho-specific antibody. GSK3 $\alpha / \beta$ protein expression was normalised to total GSK3 protein expression and the fold change was calculated relative to no labour group. Data is displayed as mean \pm S.E.M. ${ }^{*} P<0.05$ vs no labour (Student's $t$-test). (C, F and I) Representative western blot from three patients per group is also shown.

Detection System (Bio-Rad Laboratories). Average gene $C_{\mathrm{T}}$ values were normalised to the average $G A P D H C_{\mathrm{T}}$ values of the same cDNA sample and fold differences were determined using the comparative $C_{\mathrm{T}}$ method. For the explant studies, fold change was calculated relative to LPS, FSL1 or flagellin, which was set at 1 . For the cell siRNA studies, fold change was calculated relative to IL1 $\beta$ - or TNF $\alpha$-stimulated NC siRNA transfected cells, which was set at 1 .

\section{Cytokine and prostaglandin assays}

Assessment of IL6, IL8 and TNF $\alpha$ cytokine release was performed using CytoSet sandwich ELISA, according to the manufacturer's instructions (Life Technologies). The limit of detection of the IL6, IL8 and TNF $\alpha$ assays was 16, 12 and $7.2 \mathrm{pg} / \mathrm{ml}$ respectively. The release of IL $1 \beta$ was performed using DuoSet sandwich ELISA according to the manufacturer's instructions (R\&D Systems, Minneapolis, MN, USA). The limit of detection of the IL1 $\beta$ assay was $1.9 \mathrm{pg} / \mathrm{ml}$. The release of $\mathrm{PGE}_{2}$ and $\mathrm{PGF}_{2 \alpha}$ into the incubation medium was assayed using a commercially available competitive enzyme immunoassay kit according to the manufacturer's specifications (Kookaburra Kits from Sapphire Bioscience). The limit of detection of the $\mathrm{PGE}_{2}$ and $\mathrm{PGF}_{2 \alpha}$ assays was 16 and $60 \mathrm{pg} / \mathrm{ml}$ respectively. For all assays, the interassay and intraassay coefficients of variation were $<10 \%$. 

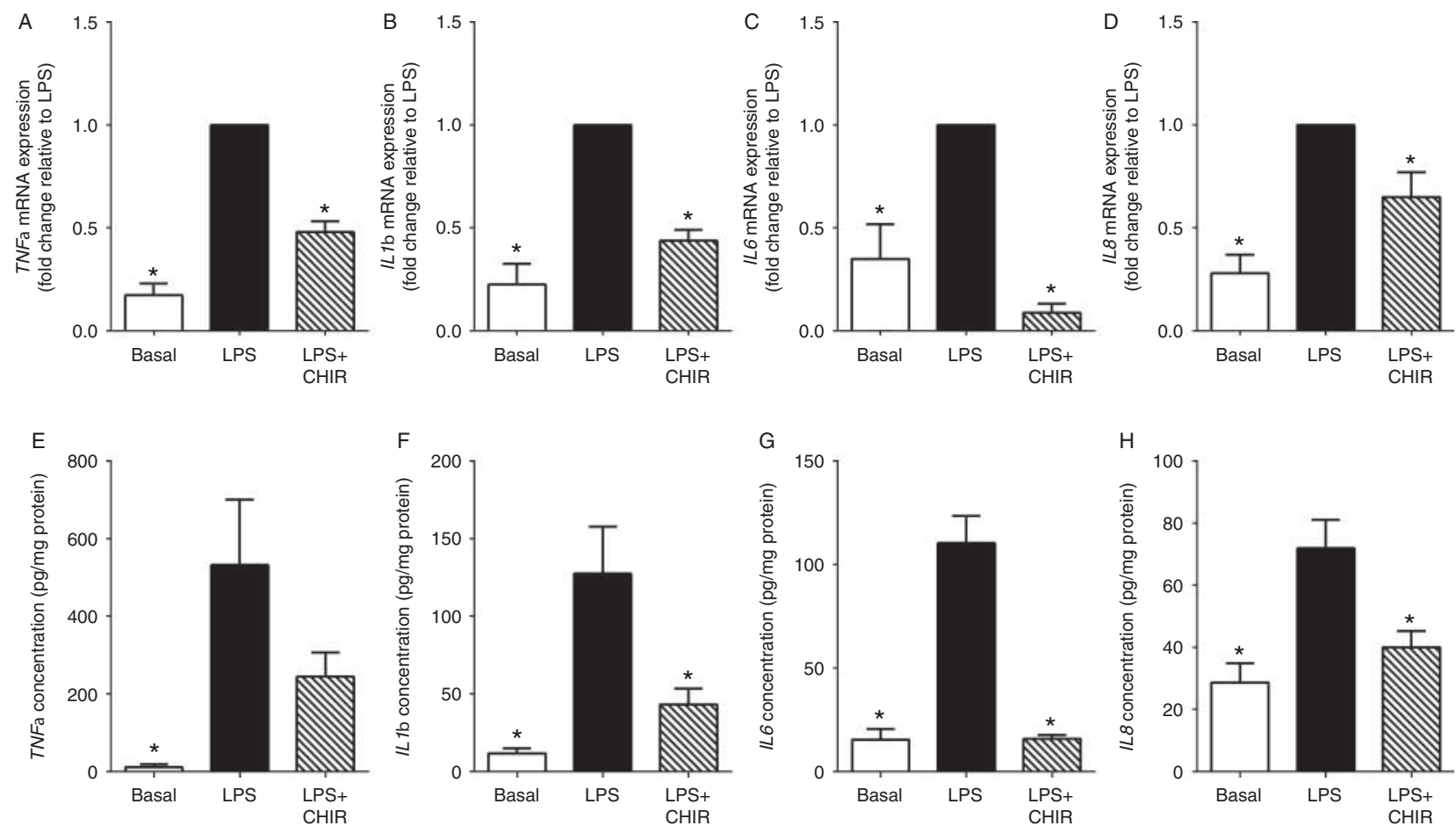

Figure 2 Effect of a GSK3 inhibitor on LPS-stimulated pro-inflammatory cytokine expression in foetal membranes. Human foetal membranes obtained from women not in labour at term Caesarean section were incubated with $10 \mu \mathrm{g} / \mathrm{ml}$ LPS in the absence or presence of $10 \mu \mathrm{M} C H \mathrm{R} 99021$ (CHIR) for $20 \mathrm{~h}$ ( $n=6$ patients). (A, B, C and D) Gene expression for TNF $\alpha, I L 1 \beta$, IL6 and IL8 was analysed by qRT-PCR. Gene expression was normalised to GAPDH mRNA expression and the fold change was calculated relative to LPS. Data displayed as mean \pm s.E.M. $* P<0.05$ vs $L P S$ (one-way ANOVA). (E, F, G and H) The incubation medium was assayed for concentration of TNF $\alpha$, IL1 $\beta$, IL6 and IL8 release by ELISA.

Data displayed as mean \pm S.E.M. $* P<0.05$ vs LPS (one-way ANOVA).

\section{$N F K B$ luciferase assay}

A luciferase assay was used to determine possible interactions between GSK3 $\beta$ and NFKB, as described previously (Lappas 2013, Lim et al. 2013a), with some modifications. For these studies, primary myometrial cells, prepared as described previously, at $\sim 70 \%$ confluence were transfected with the FuGENE HD Transfection Reagent (Promega) according to the manufacturer's guidelines. The cells were co-transfected with $0.15 \mu \mathrm{g} N F \kappa \mathrm{B}$ reporter construct (Qiagen) plus $200 \mathrm{nM} \mathrm{NC}$ siRNA or GSK3 $\beta$ siRNA for $48 \mathrm{~h}$. The medium was then replaced with DMEM/F-12 with $0.5 \% \mathrm{BSA}$, with or without $1 \mathrm{ng} / \mathrm{ml} \mathrm{IL} 1 \beta$ or $10 \mathrm{ng} / \mathrm{ml} \mathrm{TNF} \alpha$, and the cells were incubated at $37^{\circ} \mathrm{C}$ for an additional $24 \mathrm{~h}$. The cells were harvested in lysis buffer, and the luminescence activity was measured using the Luciferase Reporter Assay Kit (Life Research) and Renilla Luciferase Flash Assay Kit (Thermo Fisher Scientific, Scoresby, VIC, Australia) as instructed. The ratio of the firefly luciferase level to the Renilla luciferase level was determined and the results are expressed as a ratio of normalised luciferase activity of IL1 $\beta$ - or TNF $\alpha$-stimulated NFKB reporter plus NC siRNAtransfected cells, which was set as 1 . The experiments were performed from the myometrium obtained from five patients.

\section{Statistical analyses}

Statistics was performed on the normalised data unless otherwise specified. All statistical analyses were undertaken using GraphPad Prism (GraphPad Software, La Jolla, CA, USA). For two-sample comparisons, either a paired or unpaired Student's t-test was used to assess statistical significance between normally distributed data; otherwise, the nonparametric Mann-Whitney $U$ (unpaired) or the Wilcoxon (matched pairs) tests were used. For all other comparisons, the homogeneity of data was assessed by the Bartlett's test, and when significant, the data were logarithmically transformed before further analysis using a one-way ANOVA (with Fishers least significant difference (LSD) post-hoc testing to discriminate among the means). Statistical significance was ascribed to $P$ value $<0.05$. Data were expressed as mean \pm s.E.M.

\section{Results}

\section{Effect of human term or preterm labour on phosphory- lated GSK $3 \alpha / \beta$ expression in foetal membranes and myometrium}

Western blotting analysis was carried out to determine the effect of human term or preterm labour on GSK3 $\alpha / \beta$ activity. The inactivation of GSK3 activity can be induced by phosphorylation at one of its N-terminal serine (Ser) residues: Ser21 for GSK3 $\alpha$ (51 kDa) and Ser9 for GSK3 $\beta$ (47 kDa). All data were normalised to total GSK3 $\beta$ expression.

The foetal membranes were obtained at term Caesarean section in the absence of labour (no labour) or after 

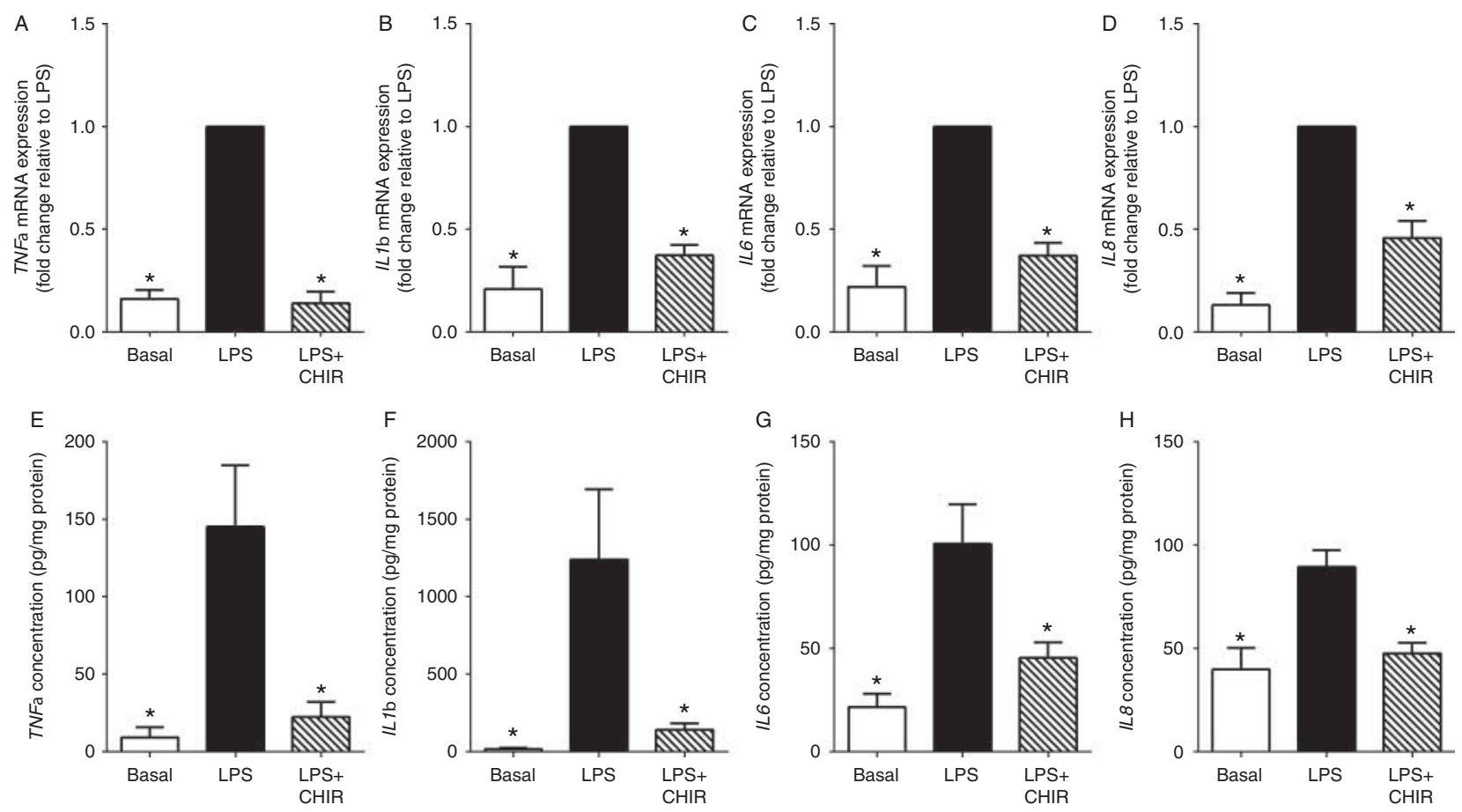

Figure 3 Effect of a GSK3 inhibitor on LPS-stimulated pro-inflammatory cytokine expression in myometrium. Human myometrium obtained from

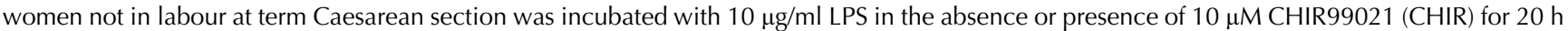
( $n=6$ patients). (A, B, C and D) Gene expression for TNF $\alpha, I L 1 \beta, I L 6$ and IL 8 was analysed by qRT-PCR. Gene expression was normalised to GAPDH mRNA expression and the fold change was calculated relative to LPS. Data displayed as mean \pm s.E.M. $* P<0.05$ vs LPS (one-way ANOVA). (E, F, G and $H$ ) The incubation medium was assayed for the concentration of TNF $\alpha$, IL1 $\beta$, IL6 and IL8 release by ELISA. Data displayed as mean \pm s.E.M. $* P<0.05$ vs LPS (one-way ANOVA).

spontaneous labour and membrane rupture (after labour) ( $n=8$ patients/group). There was no change in phosphorylated serine GSK3 $\alpha$ expression in the foetal membranes after labour (Fig. 1A). On the other hand, phosphorylated GSK3 $\beta$ was significantly higher in nonlabouring foetal membranes compared with labouring foetal membranes (Fig. 1B). A representative western blotting is shown in Fig. 1C.

Myometrium was obtained at term Caesarean section in the absence of labour (no labour) or during spontaneous labour onset (in labour) ( $n=8$ patients/ group). There was no change in phosphorylated serine GSK3 $\alpha$ (Fig. 1D) or GSK3 $\beta$ (Fig. 1E) expression. A representative western blotting is shown in Fig. 1F.

The foetal membranes were obtained from women at preterm Caesarean section in the absence of labour or after spontaneous preterm labour and normal vaginal delivery ( $n=8$ patients/group). Women with preterm deliveries were matched for maternal age, BMI, gravidity, parity and gestational age. Phosphorylated serine GSK3 $\alpha$ (Fig. $1 \mathrm{G}$ and I) and GSK3 $\beta$ (Fig. $1 \mathrm{H}$ and I) expression was significantly lower after spontaneous preterm labour. Western blotting could not be performed on foetal membranes from the chorioamnionitis group due to protein degradation (Holdsworth-Carson et al. 2009).

\section{Effect of GSK3 inhibitor on pro-labour mediators in human foetal membranes and myometrium in the presence of bacterial endotoxin LPS}

We next sought to determine the effect of a specific GSK3 inhibitor, CHIR99021, on the expression and secretion of pro-inflammatory and pro-labour mediators in foetal membranes and myometrium in the presence of bacterial endotoxin LPS.

As expected, treatment with LPS induced a significant increase in $T N F \alpha, I L 1 \beta, I L 6$ and IL 8 mRNA expression and secretion in both foetal membranes (Fig. 2) and myometrium (Fig. 3). In foetal membranes, co-treatment with CHIR99021 significantly attenuated LPS-induced IL1 $\beta$, IL6 and IL8 mRNA expression and secretion and $T N F \alpha$ gene expression (Fig. 2). In myometrium, co-treatment with CHIR99021 significantly attenuated LPS-induced gene expression and secretion of $T N F \alpha$, IL $1 \beta$, IL6 and IL 8 (Fig. 3). For both foetal membranes and myometrium, there was no effect of CHIR99021 on cytokine release under basal conditions (data not shown).

Myometrium treated with LPS significantly increased COX2 mRNA expression (Fig. 4A), and the release of $\mathrm{PGE}_{2}$ (Fig. 4B) and $\mathrm{PGF}_{2 \alpha}$ (Fig. 4C). Co-treatment with CHIR99021 was associated with a significant dampening of COX2 mRNA expression, and $\mathrm{PGE}_{2}$ and $\mathrm{PGF}_{2 \alpha}$ release in response to LPS. There was no effect of LPS 

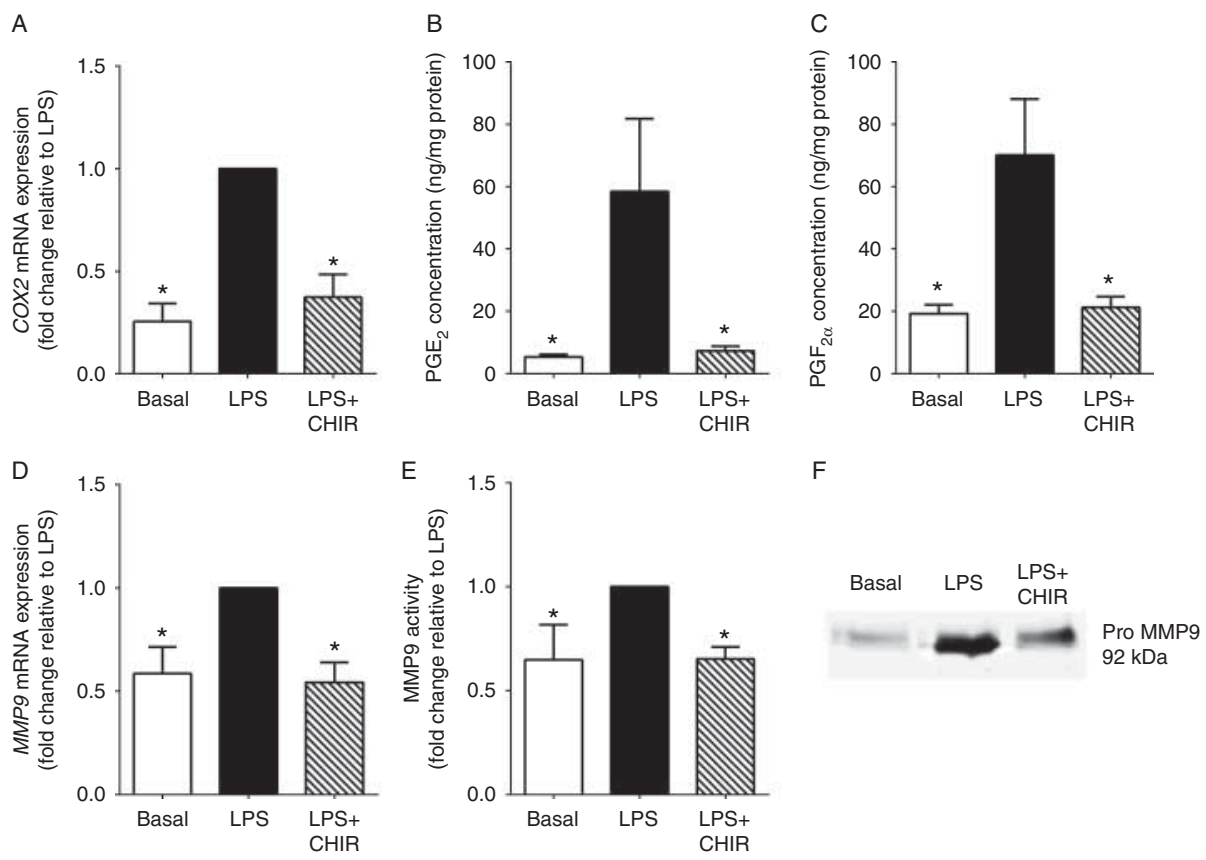

Figure 4 Effect of a GSK3 inhibitor on LPS-stimulated COX2-prostaglandin pathway and MMP9 expression in myometrium. Human myometrium obtained from women not in labour at term Caesarean section was incubated with $10 \mu \mathrm{g} / \mathrm{ml}$ LPS in the absence or presence of $10 \mu \mathrm{M}$ CHIR99021 (CHIR) for $20 \mathrm{~h}$ ( $n=6$ patients). (A and D) Gene expression for COX2 and MMP9 was analysed by qRT-PCR. Gene expression was normalised to GAPDH mRNA expression and the fold change was calculated relative to LPS. Data displayed as mean \pm s.E.M. ${ }^{*} P<0.05$ vs LPS (one-way ANOVA). $(\mathrm{B}$ and $\mathrm{C})$ The incubation medium was assayed for the concentration of $\mathrm{PGE}_{2}$ and $\mathrm{PGF}_{2 \alpha}$ release by ELISA. Data displayed as mean \pm s.E.M. $* P<0.05$ vs LPS (one-way ANOVA). (E) The incubation medium was assayed for enzymatic activity of MMP9 by gelatin zymography. Data displayed as mean \pm s.E.M. $* P<0.05$ vs LPS (one-way ANOVA). (F) Representative gelatin zymography image from one patient.

with or without CHIR99021 on COX1 mRNA expression (data not shown). There was also no effect of CHIR99021 on basal prostaglandin release (data not shown).

Myometrium treated with LPS significantly increased MMP9 mRNA expression (Fig. 4D) and secretory pro MMP9 expression (Fig. 4E and F). Co-treatment with CHIR99021 significantly decreased LPS-stimulated expression of MMP9 mRNA and secretory pro MMP9. There was no effect of LPS or CHIR99021 on MMP2 mRNA expression or the secretion of pro MMP2 (data not shown).

\section{Effect of a GSK3 inhibitor on pro-labour mediators in human foetal membranes and myometrium in the presence of the bacterial products FSL1 and flagellin}

Our previous studies have shown that bacterial products FSL1 (TLR2 ligand) and flagellin (TLR5 ligand) increase pro-labour mediators in human gestational tissues (Lim et al. 2014a). Thus, we sought to determine whether GSK3 also regulates TLR2- and TLR5-induced inflammation in foetal membranes and myometrium. As expected, treatment with FSL1 (Fig. 5A, B, C and D) and flagellin (Fig. 6A, B, C and D) induced a significant increase in IL6 and IL 8 mRNA expression and secretion in foetal membranes. Co-treatment with CHIR99021 significantly attenuated FSL1- and flagellin-induced cytokine gene expression and secretion in foetal membranes. Similarly, in myometrium, treatment with FSL1 (Fig. 5E, F, G and H) or flagellin (Fig. 6E, F, G and H) induced a significant increase in IL6 and IL8 mRNA expression and secretion. Co-treatment with CHIR99021 significantly decreased FSL1- or flagellin-induced IL6 and IL8 gene expression and secretion. For both foetal membranes and myometrium, the release of TNF $\alpha$ and IL1 $\beta$ in the presence of FSL1 or flagellin was below the sensitivity of the assay.

Treatment with FSL1 significantly increased COX2 mRNA expression (Fig. 7A) and release of $\mathrm{PGE}_{2}$ (Fig. 7B) and PGF $_{2 \alpha}$ (Fig. 7C). Co-treatment with CHIR99021 significantly decreased FSL1-induced COX2 mRNA expression and release of $\mathrm{PGE}_{2}$ and $\mathrm{PGF}_{2 \alpha}$. Treatment with flagellin significantly increased COX2 mRNA expression (Fig. 7D) and release of $\mathrm{PGE}_{2}$ (Fig. 7E) and $\mathrm{PGF}_{2 \alpha}$ (Fig. 7F). Co-treatment with CHIR99021 significantly decreased flagellin-induced COX2 mRNA expression, but not the release of $\operatorname{PGE}_{2}(P=0.06)$ and $\operatorname{PGF}_{2 \alpha}(P=0.06)$.

\section{Effect of GSK3 $\beta$ siRNA on pro-labour mediators in primary myometrium cells}

The final aim of this study was to determine the effect of GSK3 $\beta$ siRNA on pro-inflammatory and pro-labour mediators. We specifically used siRNA against the $\beta$ isoform as studies in non-gestational tissues have shown 
Foetal membranes
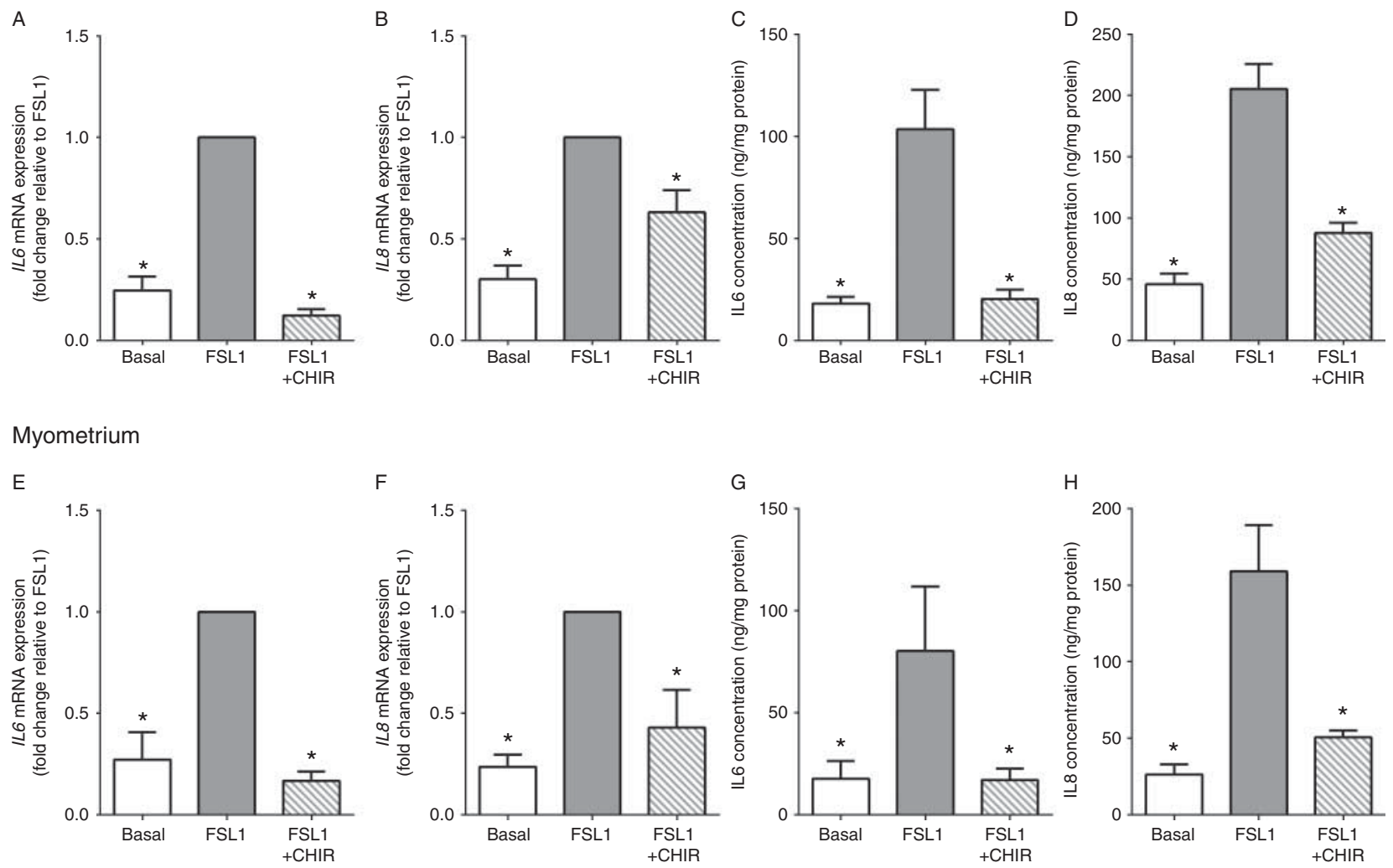

Figure 5 Effect of a GSK3 inhibitor on FSL1-stimulated pro-inflammatory cytokines in foetal membranes and myometrium. (A, B, C and D) Human foetal membranes ( $n=6$ patients) and (E, F, G and $\mathrm{H}$ ) myometrium ( $n=4$ patients) obtained from women not in labour at term Caesarean section were incubated with $250 \mathrm{ng} / \mathrm{ml}$ FSL1 in the absence or presence of $10 \mu \mathrm{M} \mathrm{CHIR99021} \mathrm{(CHIR)} \mathrm{for} 20 \mathrm{~h}$. (A, B, E and F) Gene expression for IL6 and IL8 was analysed by qRT-PCR. Gene expression was normalised to GAPDH mRNA expression and the fold change was calculated relative to FSL1. Data displayed as mean \pm s.E.M. ${ }^{*} P<0.05$ vs FSL1 (one-way ANOVA). (C, D, G and H) The incubation medium was assayed for concentration of IL6 and IL8 release by ELISA. Data displayed as mean \pm s.E.M. ${ }^{*} P<0.05$ vs FSL1 (one-way ANOVA).

that the $\beta$ isoform is more important in the context of inflammation (Takada et al. 2004, Dugo et al. 2005, Martin et al. 2005, Jope et al. 2007). For these studies, we used primary myometrial cells isolated from fresh myometrial tissue. The efficacy of transfection was analysed by western blotting and a representative image is presented in Fig. 8A; protein expression of GSK3 $\beta$ was decreased by $\sim 50 \%$ in GSK3 $\beta$ siRNAtransfected cells. MTT cell viability assay showed that when compared with NC siRNA-transfected cells, there was no significant effect of GSK3 $\beta$ siRNA on cell viability (absorbance at $570 \mathrm{nM}$ for NC siRNA $0.27 \pm 0.20$ vs GSK3 $\beta$ siRNA $0.33 \pm 0.21$ ).

For subsequent experiments, after siRNA transfection, cells were treated with either IL1 $\beta$ or TNF $\alpha$, as these pro-inflammatory cytokines are known to be increased in human gestational tissues with labour and can induce preterm labour in animal models. Figure 8 also describes the effects of GSK3 $\beta$ knockdown by siRNA on IL1 $\beta$ induced secretion of pro-inflammatory cytokines and prostaglandins. Compared with basal NC siRNA, there was a significant increase in IL6 (Fig. 8B), IL8 (Fig. 8C) and $\mathrm{PGF}_{2 \alpha}$ (Fig. 8F) release in NC siRNA-transfected cells treated with IL $1 \beta$. This increase was significantly attenuated in GSK3 $\beta$ siRNA-transfected cells. Similarly, in cells treated with TNF $\alpha$, the increase in IL6 (Fig. 8D) and IL8 (Fig. 8E) release was significantly reduced in GSK3 $\beta$ siRNA-transfected cells. The effect of GSK3 $\beta$ siRNA on IL1 $\beta$-induced $\mathrm{PGE}_{2}$ release was unable to be detected, being below the assay reading range. Both $\mathrm{PGE}_{2}$ and $\mathrm{PGF}_{2 \alpha}$ were unable to be detected in transfected cells treated with TNF $\alpha$.

\section{Silencing of GSK3 $\beta$ represses NFKB p65 transcriptional activity}

To determine whether GSK3 $\beta$ regulates pro-labour mediators in primary myometrial cells through $N F \kappa B$, a luciferase assay was used as we have described previously (Lappas 2013). As shown in Fig. 9A, in NC siRNA transfected myometrial cells, IL1 $\beta$ significantly increased NFKB p65 luciferase activity. However, luciferase activity was significantly decreased in GSK3 $\beta$ siRNA-transfected cells. Similar results were 
Foetal membranes
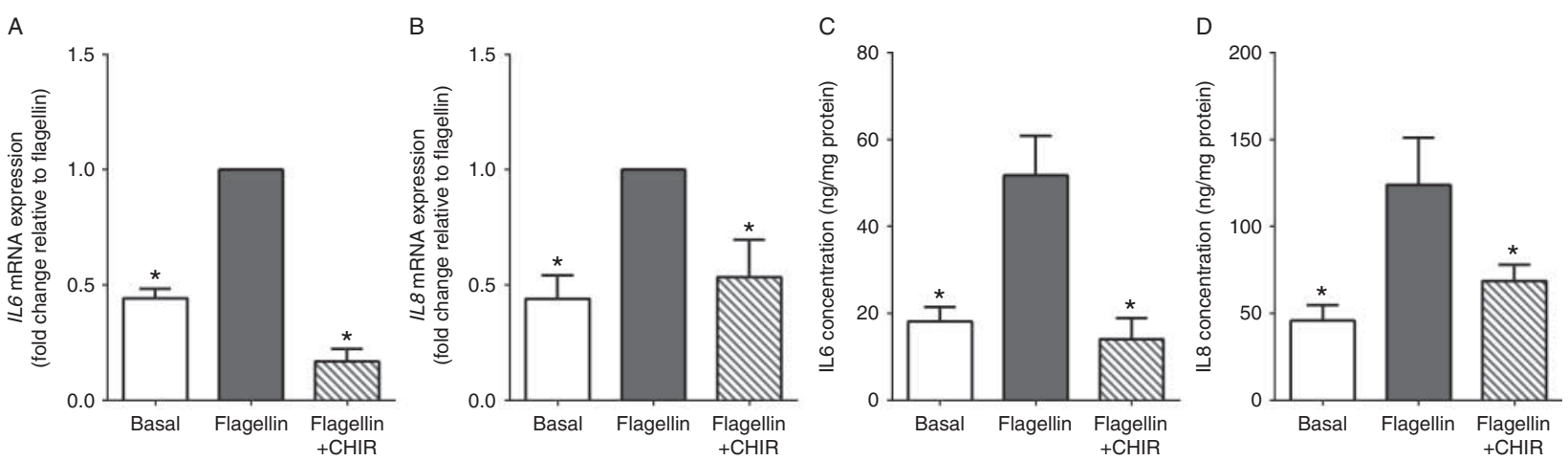

Myometrium
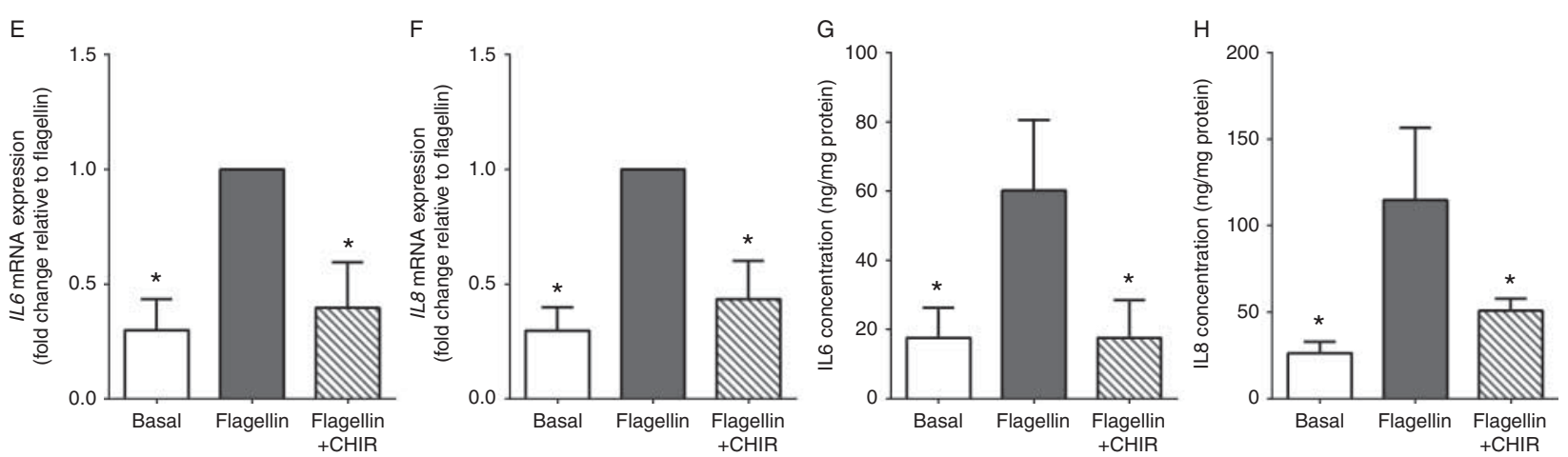

Figure 6 Effect of a GSK3 inhibitor on flagellin-stimulated pro-inflammatory cytokine expression in foetal membranes and myometrium. (A, B, C and D) Human foetal membranes ( $n=6$ patients) and (E, F, G and H) myometrium ( $n=4$ patients) obtained from women not in labour at term Caesarean section were incubated with $1 \mu \mathrm{g} / \mathrm{ml}$ flagellin in the absence or presence of $10 \mu \mathrm{M} \mathrm{CHIR99021}$ (CHIR) for $20 \mathrm{~h}$. (A, B, E and F) Gene expression for IL6 and IL8 was analysed by qRT-PCR. Gene expression was normalised to GAPDH mRNA expression and the fold change was calculated relative to flagellin. Data displayed as mean \pm s.E.M. ${ }^{*} P<0.05$ vs flagellin (one-way ANOVA). (C, D, G and H) The incubation medium was assayed for concentration of IL6 and IL8 release by ELISA. Data displayed as mean \pm s.E.M. ${ }^{*} P<0.05$ vs flagellin (one-way ANOVA).

obtained with cells treated with TNF $\alpha$, where cells transfected with GSK3 $\beta$ siRNA decreased TNF $\alpha$ stimulated NFKB luciferase activity (Fig. 9B).

\section{Discussion}

This study provides, for the first time, evidence that GSK3 is an important regulatory protein involved in inflammatory processes in foetal membranes and myometrium. In this work, we showed that GSK3 activity is increased in foetal membranes after term and preterm labour onset and delivery. GSK3 activity, however, was not significantly increased with term labour in myometrium. In this study, tissues were treated in the presence of TLR ligands and bacterial products LPS, FSL1 and flagellin, to mimic preterm labour in order to define the importance of GSK3 in the expression of pro-inflammatory cytokines, prostaglandins and proteases. We found that the chemical inhibitor of GSK3, CHIR99021, could efficiently prevent the expression and release of prolabour mediators in foetal membranes and myometrium that were stimulated with the TLR4 ligand LPS, the TLR5 ligand flagellin and the TLR2 ligand FSL1. In addition to its role in TLR signalling, we also showed that GSK $\beta$ plays a role in IL $1 \beta$ and TNF $\alpha$ signalling. Specifically, in cells transfected with siRNA against GSK3 $\beta$, there was a significant decrease in IL1 $\beta$ and TNF $\alpha$-stimulated cytokine and prostaglandin release. Notably, a luciferase assay demonstrated a decrease in NFKB p65 transcriptional activity in cells co-transfected with GSK3 $\beta$ siRNA, suggesting that GSK3 may mediate its pro-inflammatory effects via the NFKB pathway.

GSK3 activity was increased in the foetal membranes obtained after spontaneous term and preterm labour compared with gestational-age matched foetal membranes obtained at Caesarean section in the absence of labour. We were unable to study the effects of preterm labour on myometrium, due to lack of suitable samples. The increase in GSK3 activity in foetal membranes may be a consequence of the labour processes. For example, sterile inflammation plays a central role in the terminal processes of normal human term labour and delivery (Keelan et al. 2003, Osman et al. 2003). Indeed, it has been shown that TNF $\alpha$ induces GSK3 activity in nongestational tissues (Park et al. 2011). While term labour is due to physiological activation of the labour processes, 


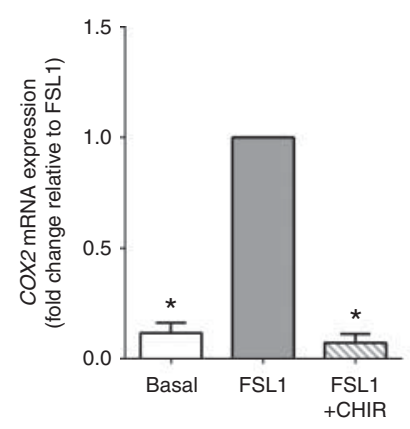

D

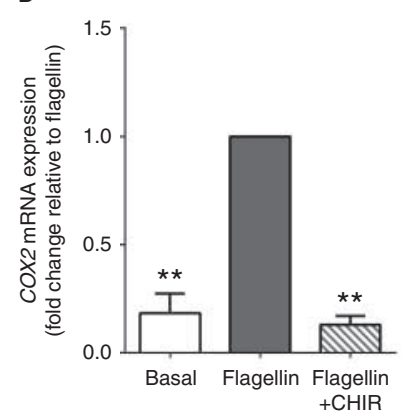

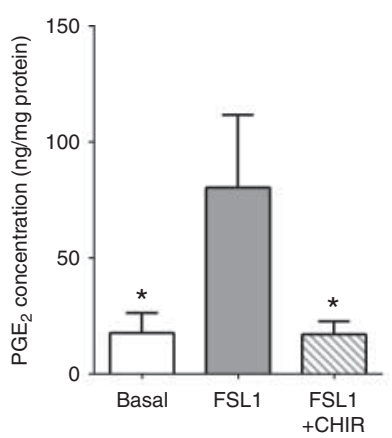

$\mathrm{E}$

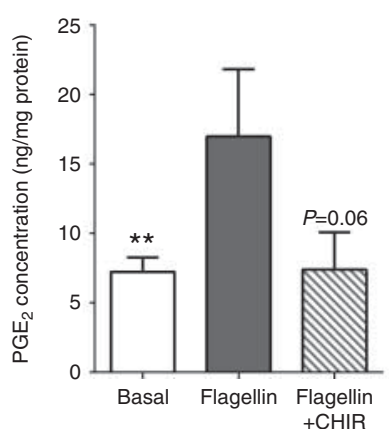

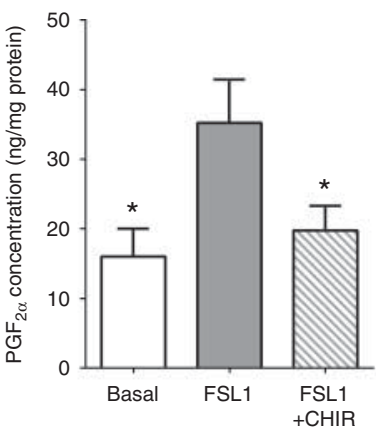

$\mathrm{F}$

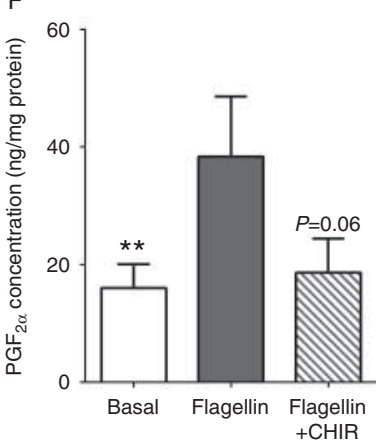

Figure 7 Effect of a GSK3 inhibitor on FSL1 and flagellin-stimulated COX2-prostaglandin pathway in myometrium. Human myometrium obtained from women not in labour at term Caesarean section was incubated with (A, B and C) $250 \mathrm{ng} / \mathrm{ml} F S L 1$ or (D, E and F) $1 \mu \mathrm{g} / \mathrm{ml}$ flagellin in the absence or presence of $10 \mu \mathrm{M} \mathrm{CHIR99021} \mathrm{(CHIR)} \mathrm{for} 20 \mathrm{~h}$ ( $n=4$ patients). (A and D) Gene expression for COX2 was analysed by qRT-PCR. Gene expression was normalised to GAPDH mRNA expression and the fold change was calculated relative to FSL1 or flagellin. Data displayed as mean \pm s.E.M. $* P<0.05$ vs FSL1 (one-way ANOVA) and ${ }^{*} P<0.05$ vs flagellin (one-way ANOVA). (B, C, E and F) The incubation medium was assayed for concentration of $\mathrm{PGE}_{2}$ and $\mathrm{PGF}_{2 \alpha}$ release by ELISA. Data displayed as mean \pm s.E.M. ${ }^{*} P<0.05$ vs FSL1 (one-way ANOVA) and $* * P<0.05$ vs flagellin (one-way ANOVA).

preterm labour is the result of pathological insults such as bacterial infection, smoking and $\mathrm{APH}$ (Romero et al. 2006). Thus, the increase in GSK3 activity after preterm labour may be due to the bacterial and/or pathological activation of labour processes associated with preterm birth. In support, GSK3 activity is increased with LPS (Martin et al. 2005), cigarette smoke (Cohen \& Goedert 2004) and thrombin (Gushiken et al. 2009).

Bacterial products such as LPS, FSL1 and flagellin have been shown to increase the expression of pro-inflammatory cytokines, prostaglandins and MMPs in foetal membranes and myometrium (Lappas 2013, Lim et al. 2014a) which participate in the terminal processes of human labour and delivery; i.e. cervical ripening, myometrial contractions and rupture of foetal membranes (Bowen et al. 2002, Olson 2003, Lappas \& Rice 2004, Romero et al. 2006, Christiaens et al. 2008). Thus, to determine whether GSK3 regulates bacterial infection-induced inflammation in human gestational tissues, we used the chemical GSK3 inhibitor CHIR99021. The current study describes novel data in that the GSK3 inhibitor CHIR99021 can attenuate the effects of LPS, flagellin and FSL1-induced pro-inflammatory cytokines in foetal membranes and myometrium. Likewise, in non-gestational tissues, inhibition of GSK3 decreases
LPS-stimulated TNF $\alpha$ and IL6 production in microglia (Yuskaitis \& Jope 2009, Wang et al. 2010) and dendritic cells (Rodionova et al. 2007), and TLR-induced IL6 and IL1 $\beta$ production in monocytes (Martin et al. 2005).

$\mathrm{TNF} \alpha$ and IL $1 \beta$ are two pro-inflammatory cytokines that can induce preterm labour in animal models (Sadowsky et al. 2006). They can also incite the production of other labour mediators; increased COX2 expression and prostaglandin synthesis (Molnar et al. 1993, Kniss et al. 1997), and MMPs in the myometrium (Roh et al. 2000) and foetal membranes (Vadillo-Ortega \& Estrada-Gutierrez 2005). Thus, to determine if GSK3 also regulates pro-inflammatory and pro-labour mediators in the presence of TNF $\alpha$ or IL1 $\beta$, we used siRNA against GSK3 $\beta$ in primary myometrial cells. We found that myometrial cells transfected with GSK3 $\beta$ siRNA released significantly less IL6 and IL8 when stimulated with IL1 $\beta$ or TNF $\alpha$. GSK3 $\beta$ siRNA-transfected cells also displayed decreased IL1 $\beta$-induced prostaglandin $\mathrm{PGF}_{2 \alpha}$ release. It is worth noting, that we did not assess the effect of siRNA knockdown of the $\alpha$ isoform of GSK3 on pro-labour mediators. Given that GSK3 $\alpha$ (in addition to GSK3 $\beta$ ) was decreased in foetal membranes after preterm labour, it is possible that it may also play a role in the regulation of cytokine-induced inflammation. 
A

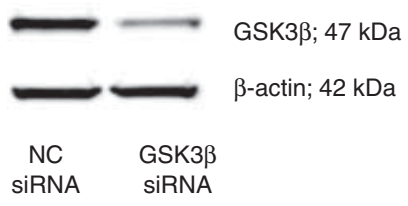

D

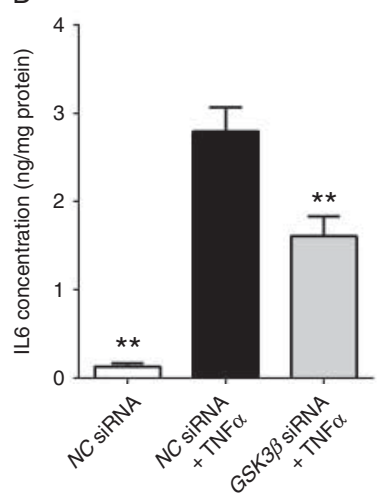

B

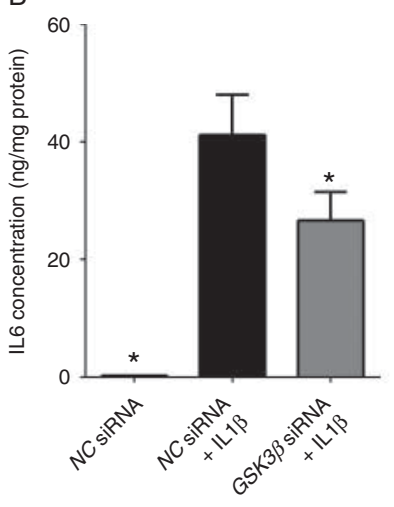

E

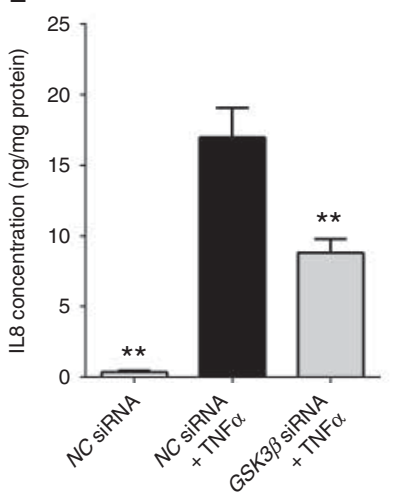

C

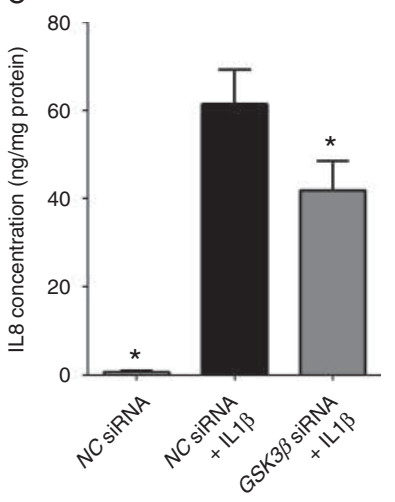

F

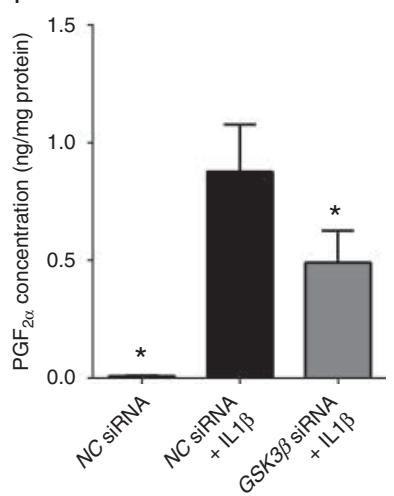

Figure 8 Effect of GSK3 $\beta$ siRNA on pro-inflammatory cytokine and prostaglandin release in primary myometrial cells. (A) Human primary myometrial cells isolated from myometrium obtained women not in labour at term Caesarean section were transfected with or without $200 \mathrm{nM}$ GSK3 $\beta$ or NC siRNA for $48 \mathrm{~h}$ ( $n=5$ patients). Representative western blotting of GSK3 $\beta$ protein expression. (B, C, D, E and F) Human primary myometrial cells were transfected with or without $200 \mathrm{nM} \mathrm{GSK3 \beta}$ or NC siRNA for $48 \mathrm{~h}$ then treated with (B, C and F) $1 \mathrm{ng} / \mathrm{ml}$ IL1 $\beta$ or (D and E) $10 \mathrm{ng} / \mathrm{ml} \mathrm{TNF} \alpha$ for an additional $24 \mathrm{~h}$ ( $n=5$ patients). The incubation medium was assayed for the concentration of (B and D) IL6, (C and E) IL8 and (F) $\mathrm{PGE}_{2}$ release by ELISA. Data displayed as mean \pm s.E.M. ${ }^{*} P<0.05$ vs IL1 $\beta$-stimulated NC siRNA transfected cells (one-way ANOVA) and $* * P<0.05$ vs TNF $\alpha$-stimulated NC siRNA transfected cells (one-way ANOVA).

Nevertheless, out data indicates that GSK3 is important, not only to TLR signalling, but also to TNF $\alpha$ and IL $1 \beta$ signalling pathways associated with preterm birth.

Our study describes for the first time that CHIR99021 can reduce LPS, FSL1 and flagellin-induced expression of COX2 mRNA expression and subsequent release of $\mathrm{PGE}_{2}$ and $\mathrm{PGF}_{2 \alpha}$ in myometrium. Gene silencing of $G S K 3 \beta$ using siRNA was also associated with a decrease in IL1 $\beta$-induced $\mathrm{PGF}_{2 \alpha}$ release. The COX2-prostaglandin pathway is integral in the initiation of labour, namely uterine contractions (Olson 2003). Our study also describes for the first time the effect of a GSK3 inhibitor on LPS-induced MMP9 mRNA and pro MMP9 expression in myometrium. We did not look at the effect of CHIR99021 on LPSinduced MMP9 expression in foetal membranes, as LPS does not stimulate MMP9 in our tissue explants. Increased activity of $M M P 9$ in human myometrium is a requirement for uterine tissue remodelling during labour and the post-partum period (Roh et al. 2000).

GSK3 is necessary for the full transcriptional activity of NFKB (Hoeflich et al. 2000, Martin et al. 2005).
The association between GSK3 and NFKB is of particular interest to this study given that $\mathrm{NF} \kappa \mathrm{B}$ regulates proinflammatory and pro-labour mediators in human gestational tissues (Lappas et al. 2002, Lappas \& Rice 2007, Keelan et al. 2009). In this study, inhibition of GSK3 $\beta$ by siRNA in human myometrial cells is associated with decreased IL1 $\beta$ - or TNF $\alpha$-induced $N F \kappa B$ transcriptional activity. Given that $N F \kappa B$ is a central regulator of TLR and cytokine-induced proinflammatory cytokines, prostaglandins and MMPs in human gestational tissues (Lappas et al. 2002, Keelan et al. 2009, Lim et al. 2014a), our data suggest that GSK3 plays a role in TLR and cytokine signalling via NFKB.

The involvement of GSK3 as a regulator of inflammation makes inhibition of GSK3 using synthetic compounds an attractive avenue of research; notably, it was shown that GSK3 inhibitors provided protection against inflammation after TLR stimulation in animal models (Martin et al. 2005). Our study demonstrates that in both foetal membranes and myometrium, CHIR99021 decreased the production of pro-inflammatory and 

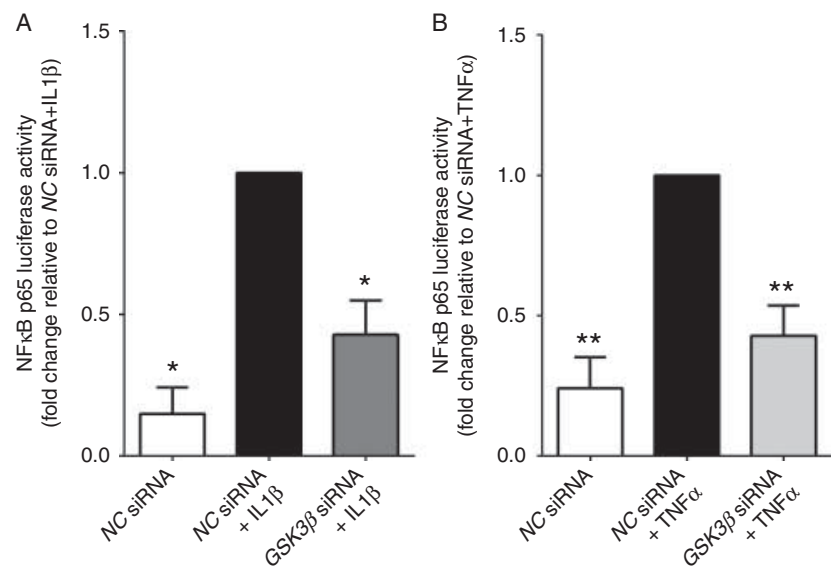

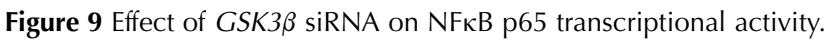
Human myometrial cells isolated from myometrium obtained women not in labour at term Caesarean section were co-transfected with

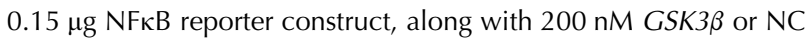
siRNA for $48 \mathrm{~h}$, then treated with (A) $1 \mathrm{ng} / \mathrm{ml} \mathrm{IL1} 1 \beta$ or (B) $10 \mathrm{ng} / \mathrm{ml} \mathrm{TNF} \alpha$ for an additional $24 \mathrm{~h}$ ( $n=4$ patients). Promoter activity (normalised with Renilla expression) is expressed as a ratio of luciferase activity of IL1 $\beta$ or TNF $\alpha$-stimulated NC siRNA transfected cells. Each bar represents the mean \pm s.E.M. ${ }^{*} P<0.05$ vs IL1 $\beta$-stimulated $N C$ siRNA transfected cells (one-way ANOVA) and ${ }^{* *} P<0.05$ vs TNF $\alpha$-stimulated NC siRNA-transfected cells (one-way ANOVA).

pro-labour mediators when stimulated with LPS, flagellin and FSL1. These results offer incentive to determine whether GSK3 inhibitors can be used in a mouse model of infection-induced preterm birth to either delay preterm labour and/or reduce maternal and foetal inflammation. In support, several animal models of inflammation have demonstrated an important role for GSK $\beta$ in the modulation of stimulus-induced production of several cytokines and the subsequent development of disease symptoms. For example, inhibition or deletion of GSK3 $\beta$ was protective against experimental peritonitis and arthritis (Hu et al. 2006), renal dysfunction and hepatotoxicity associated with endotoxemia (Dugo et al. 2006), colitis (Whittle et al. 2006, Hofmann et al. 2010) and endotoxin shock (Martin et al. 2005).

\section{Conclusions}

To our knowledge, this is the first study to demonstrate the expression of GSK3 in human foetal membranes and myometrium. We have shown here that GSK3 activity is increased with human spontaneous term and preterm labour and delivery in foetal membranes. Notably, the results of this study also point to GSK3 as a novel regulator of the terminal processes of human preterm labour and delivery. Specifically, the GSK3 inhibitor CHIR99021 significantly reduced proinflammatory and pro-labour mediators when stimulated with LPS, flagellin and FSL1. In addition, inhibition of
GSK3 $\beta$ by siRNA in myometrial cells decreased IL $1 \beta$ and TNF $\alpha$-induced cytokine expression; this was associated with a decrease in NFKB transcriptional activity. These findings are of clinical relevance, particularly in the context of infection-associated preterm birth. Our results provide a rationale for including GSK3 among the potential molecular targets for the therapy of preterm birth.

\section{Declaration of interest}

The authors declare that there is no conflict of interest that could be perceived as prejudicing the impartiality of the research reported.

\section{Funding}

Associate Professor M Lappas is supported by a Career Development Fellowship from the National Health and Medical Research Council (NHMRC; grant number 1047025). Dr R Lim was, in part, supported by an early career researcher grant from the University of Melbourne. Additional funding was provided from the Medical Research Foundation for Women and Babies.

\section{Acknowledgements}

The authors gratefully acknowledge the following: Gillian Barker for her excellent technical assistance (Obstetrics, Nutrition and Endocrinology Group, Department of Obstetrics and Gynaecology, University of Melbourne, Victoria, Australia); Clinical Research Midwives Genevieve Christophers, Gabrielle Pell, Debra Jinks and Rachel Murdoch for sample collection; and the Obstetrics and Midwifery staff of the Mercy Hospital for Women for their co-operation.

\section{References}

Adams-Chapman I \& Stoll BJ 2006 Neonatal infection and long-term neurodevelopmental outcome in the preterm infant. Current Opinion in Infectious Diseases 19 290-297. (doi:10.1097/01.qco.0000224825. 57976.87)

Balamurugan K, Sharan S, Klarmann KD, Zhang Y, Coppola V, Summers GH, Roger T, Morrison DK, Keller JR \& Sterneck E 2013 FBXW7 $\alpha$ attenuates inflammatory signalling by downregulating C/EBP $\delta$ and its target gene Trr4. Nature Communications 4 1662. (doi:10.1038/ ncomms2677)

Barton-Pai A, Feleder C \& Johnson A 2011 Tumor necrosis factor- $\alpha$ induces increased lung vascular permeability: a role for GSK $3 \alpha / \beta$. European Journal of Pharmacology 657 159-166. (doi:10.1016/j.ejphar. 2011.01.060)

Beurel E, Michalek SM \& Jope RS 2010 Innate and adaptive immune responses regulated by glycogen synthase kinase-3 (GSK3). Trends in Immunology 31 24-31. (doi:10.1016/j.it.2009.09.007)

Bowen JM, Chamley L, Mitchell MD \& Keelan JA 2002 Cytokines of the placenta and extra-placental membranes: biosynthesis, secretion and roles in establishment of pregnancy in women. Placenta 23 239-256. (doi:10.1053/plac.2001.0781)

Christiaens I, Zaragoza DB, Guilbert L, Robertson SA, Mitchell BF \& Olson DM 2008 Inflammatory processes in preterm and term parturition. Journal of Reproductive Immunology 79 50-57. (doi:10.1016/j.jri.2008. 04.002) 
Cohen P \& Goedert M 2004 GSK3 inhibitors: development and therapeutic potential. Nature Reviews. Drug Discovery 3 479-487. (doi:10.1038/ nrd1415)

Doble BW \& Woodgett JR 2003 GSK-3: tricks of the trade for a multi-tasking kinase. Journal of Cell Science 116 1175-1186. (doi:10.1242/jcs.00384)

Dugo L, Collin M, Allen DA, Patel NS, Bauer I, Mervaala EM, Louhelainen M, Foster SJ, Yaqoob MM \& Thiemermann C 2005 GSK-3 $\beta$ inhibitors attenuate the organ injury/dysfunction caused by endotoxemia in the rat. Critical Care Medicine 33 1903-1912. (doi:10.1097/01.CCM. 0000178350.21839.44)

Dugo L, Abdelrahman M, Murch O, Mazzon E, Cuzzocrea S \& Thiemermann C 2006 Glycogen synthase kinase-3 $\beta$ inhibitors protect against the organ injury and dysfunction caused by hemorrhage and resuscitation. Shock 25 485-491. (doi:10.1097/01.shk.0000209545. 29671.31)

Frame S \& Cohen P 2001 GSK3 takes centre stage more than 20 years after its discovery. Biochemical Journal 359 1-16. (doi:10.1042/02646021:3590001)

Goldenberg RL, Culhane JF, lams JD \& Romero R 2008 Epidemiology and causes of preterm birth. Lancet 371 75-84. (doi:10.1016/S01406736(08)60074-4)

Grimes CA \& Jope RS 2001 The multifaceted roles of glycogen synthase kinase $3 \beta$ in cellular signaling. Progress in Neurobiology 65 391-426. (doi:10.1016/S0301-0082(01)00011-9)

Gurrieri C, Piazza F, Gnoato M, Montini B, Biasutto L, Gattazzo C, Brunetta E, Cabrelle A, Cinetto F, Niero R et al. 2010 3-(2,4-Dichlorophenyl)-4(1-methyl-1H-indol-3-yl)-1H-pyrrole-2,5-dione (SB216763), a glycogen synthase kinase- 3 inhibitor, displays therapeutic properties in a mouse model of pulmonary inflammation and fibrosis. Journal of Pharmacology and Experimental Therapeutics 332 785-794. (doi:10.1124/jpet.109. 153049)

Gushiken FC, Hyojeong H, Pradhan S, Langlois KW, Alrehani N, Cruz MA, Rumbaut RE \& Vijayan KV 2009 The catalytic subunit of protein phosphatase $1 \gamma$ regulates thrombin-induced murine platelet $\alpha(\mathrm{Ilb}) \beta(3)$ function. PLoS ONE 4 e8304. (doi:10.1371/journal.pone.0008304)

Hoeflich KP, Luo J, Rubie EA, Tsao MS, Jin O \& Woodgett JR 2000 Requirement for glycogen synthase kinase- $3 \beta$ in cell survival and NF- $\kappa B$ activation. Nature 406 86-90. (doi:10.1038/35017574)

Hofmann C, Dunger N, Scholmerich J, Falk W \& Obermeier F 2010 Glycogen synthase kinase 3- $\beta$ : a master regulator of Toll-like receptormediated chronic intestinal inflammation. Inflammatory Bowel Diseases 16 1850-1858. (doi:10.1002/ibd.21294)

Holdsworth-Carson SJ, Permezel M, Rice GE \& Lappas M 2009 Preterm and infection-driven preterm labor: the role of peroxisome proliferatoractivated receptors and retinoid $X$ receptor. Reproduction 137 1007-1015. (doi:10.1530/REP-08-0496)

Hu XY, Paik PK, Chen J, Yarilina A, Kockeritz L, Lu TT, Woodgett JR \& Ivashkiv LB 2006 IFN- $\gamma$ suppresses IL-10 production and synergizes with TLR2 by regulating GSK3 and CREB/AP-1 proteins. Immunity $\mathbf{2 4}$ 563-574. (doi:10.1016/j.immuni.2006.02.014)

Jope RS \& Johnson GV 2004 The glamour and gloom of glycogen synthase kinase-3. Trends in Biochemical Sciences 29 95-102. (doi:10.1016/j. tibs.2003.12.004)

Jope RS, Yuskaitis CJ \& Beurel E 2007 Glycogen synthase kinase-3 (GSK3): inflammation, diseases, and therapeutics. Neurochemical Research 32 577-595. (doi:10.1007/s11064-006-9128-5)

Keelan JA, Blumenstein M, Helliwell RJ, Sato TA, Marvin KW \& Mitchell MD 2003 Cytokines, prostaglandins and parturition - a review. Placenta 24 (Suppl A) S33-S46. (doi:10.1053/plac.2002.0948)

Keelan JA, Khan S, Yosaatmadja F \& Mitchell MD 2009 Prevention of inflammatory activation of human gestational membranes in an ex vivo model using a pharmacological NF- $\mathrm{KB}$ inhibitor. Journal of Immunology 183 5270-5278. (doi:10.4049/jimmunol.0802660)

Kniss DA, Zimmerman PD, Garver CL \& Fertel RH 1997 Interleukin-1 receptor antagonist blocks interleukin-1-induced expression of cyclooxygenase-2 in endometrium. American Journal of Obstetrics and Gynecology 177 559-567. (doi:10.1016/S0002-9378(97)70146-7)

Lappas M 2013 NOD1 and NOD2 regulate proinflammatory and prolabor mediators in human fetal membranes and myometrium via nuclear factor-кB. Biology of Reproduction 89 14. (doi:10.1095/biolreprod.113. 110056)
Lappas M \& Rice GE 2004 Phospholipase A2 isozymes in pregnancy and parturition. Prostaglandins, Leukotrienes, and Essential Fatty Acids $\mathbf{7 0}$ 87-100. (doi:10.1016/j.plefa.2003.04.001)

Lappas M \& Rice GE 2007 The role and regulation of the nuclear factor $\kappa B$ signalling pathway in human labour. Placenta 28 543-556. (doi:10.1016/j.placenta.2006.05.011)

Lappas M, Permezel M, Georgiou HM \& Rice GE 2002 Nuclear factor $\kappa B$ regulation of proinflammatory cytokines in human gestational tissues in vitro. Biology of Reproduction 67 668-673. (doi:10.1095/biolreprod67.2.668)

Lappas M, Permezel M \& Rice GE 2006 15-Deoxy- $\Delta(12,14)$-prostaglandin $J(2)$ and troglitazone regulation of the release of phospholipid metabolites, inflammatory cytokines and proteases from human gestational tissues. Placenta 27 1060-1072. (doi:10.1016/j.placenta. 2005.11.009)

Lappas M, Mitton A, Lim R, Barker G, Riley C \& Permezel M 2011 SIRT1 is a novel regulator of key pathways of human labor. Biology of Reproduction 84 167-178. (doi:10.1095/biolreprod.110.086983)

Lawn JE, Cousens S, Zupan J \& T Lancet Neonatal Survival Steering 20054 million neonatal deaths: when? where? why? Lancet 365 891-900. (doi:10.1016/S0140-6736(05)71048-5)

Lim R, Barker G \& Lappas M 2013a SIRT6 is decreased with preterm labor and regulates key terminal effector pathways of human labor in fetal membranes. Biology of Reproduction 88 17. (doi:10.1095/biolreprod. 112.105163)

Lim R, Barker G, Riley C \& Lappas M 2013b Apelin is decreased with human preterm and term labor and regulates prolabor mediators in human primary amnion cells. Reproductive Sciences 20 957-67. (doi:10.1177/1933719112472741)

Lim R, Barker G \& Lappas M 2014a The TLR2 ligand FSL-1 and the TLR5 ligand flagellin mediate pro-inflammatory and pro-labour response via MyD88/TRAF6/NF-кB-dependent signalling. American Journal of Reproductive Immunology 71 401-417. (doi:10.1111/aji.12229)

Lim R, Barker G \& Lappas M 2014b TREM-1 expression is increased in human placentas from severe early-onset preeclamptic pregnancies where it may be involved in syncytialization. Reproductive Sciences $\mathbf{2 1}$ 562-572. (doi:10.1177/1933719113503406)

Martin M, Rehani K, Jope RS \& Michalek SM 2005 Toll-like receptormediated cytokine production is differentially regulated by glycogen synthase kinase 3. Nature Immunology 6 777-784. (doi:10.1038/ni1221)

McCormick MC 1985 The contribution of low birth weight to infant mortality and childhood morbidity. New England Journal of Medicine 312 82-90. (doi:10.1056/NEJM198501103120204)

Molnar M, Romero R \& Hertelendy F 1993 Interleukin-1 and tumor necrosis factor stimulate arachidonic acid release and phospholipid metabolism in human myometrial cells. American Journal of Obstetrics and Gynecology 169 825-829. (doi:10.1016/0002-9378(93)90011-7)

Norman JE \& Shennan AH 2013 Prevention of preterm birth - why can't we do any better? Lancet 381 184-185. (doi:10.1016/S0140-6736(12)61956-4)

Olson DM 2003 The role of prostaglandins in the initiation of parturition. Best Practice \& Research. Clinical Obstetrics \& Gynaecology 17 717-730. (doi:10.1016/S1521-6934(03)00069-5)

Osman I, Young A, Ledingham MA, Thomson AJ, Jordan F, Greer IA \& Norman JE 2003 Leukocyte density and pro-inflammatory cytokine expression in human fetal membranes, decidua, cervix and myometrium before and during labour at term. Molecular Human Reproduction 9 41-45. (doi:10.1093/molehr/gag001)

Park SH, Park-Min KH, Chen J, Hu X \& Ivashkiv LB 2011 Tumor necrosis factor induces GSK3 kinase-mediated cross-tolerance to endotoxin in macrophages. Nature Immunology 12 607-615. (doi:10.1038/ni.2043)

Ring DB, Johnson KW, Henriksen EJ, Nuss JM, Goff D, Kinnick TR, Ma ST, Reeder JW, Samuels I, Slabiak T et al. 2003 Selective glycogen synthase kinase 3 inhibitors potentiate insulin activation of glucose transport and utilization in vitro and in vivo. Diabetes 52 588-595. (doi:10.2337/diabetes.52.3.588)

Rodionova E, Conzelmann M, Maraskovsky E, Hess M, Kirsch M, Giese T, Ho AD, Zoller M, Dreger P \& Luft T 2007 GSK-3 mediates differentiation and activation of proinflammatory dendritic cells. Blood 109 1584-1592. (doi:10.1182/blood-2006-06-028951)

Roh CR, Oh WJ, Yoon BK \& Lee JH 2000 Up-regulation of matrix metalloproteinase-9 in human myometrium during labour: a cytokinemediated process in uterine smooth muscle cells. Molecular Human Reproduction 6 96-102. (doi:10.1093/molehr/6.1.96) 
Romero R, Espinoza J, Goncalves LF, Kusanovic JP, Friel LA \& Nien JK 2006 Inflammation in preterm and term labour and delivery. Seminars in Fetal \& Neonatal Medicine 11 317-326. (doi:10.1016/j.siny.2006.05.001)

Sadowsky DW, Adams KM, Gravett MG, Witkin SS \& Novy MJ 2006 Preterm labor is induced by intraamniotic infusions of interleukin-1 $\beta$ and tumor necrosis factor- $\alpha$ but not by interleukin- 6 or interleukin- 8 in a nonhuman primate model. American Journal of Obstetrics and Gynecology 195 1578-1589. (doi:10.1016/j.ajog.2006.06.072)

Steinbrecher KA, Wilson W III, Cogswell PC \& Baldwin AS 2005 Glycogen synthase kinase $3 \beta$ functions to specify gene-specific, NF- $\kappa$ Bdependent transcription. Molecular and Cellular Biology 25 8444-8455. (doi:10.1128/MCB.25.19.8444-8455.2005)

Takada Y, Fang X, Jamaluddin MS, Boyd DD \& Aggarwal BB 2004 Genetic deletion of glycogen synthase kinase-3 $\beta$ abrogates activation of $1 \kappa \mathrm{B} \alpha$ kinase, JNK, Akt, and p44/p42 MAPK but potentiates apoptosis induced by tumor necrosis factor. Journal of Biological Chemistry 279 39541-39554. (doi:10.1074/jbc.M403449200)

Vadillo-Ortega F \& Estrada-Gutierrez G 2005 Role of matrix metalloproteinases in preterm labour. BJOG: an International Journal of Obstetrics and Gynaecology 112 (Suppl 1) 19-22. (doi:10.1111/ j.1471-0528.2005.00579.x)

Wang MJ, Huang HY, Chen WF, Chang HF \& Kuo JS 2010 Glycogen synthase kinase-3 $\beta$ inactivation inhibits tumor necrosis factor- $\alpha$ production in microglia by modulating nuclear factor $\kappa \mathrm{B}$ and MLK3/JNK signaling cascades. Journal of Neuroinflammation 7 99. (doi:10.1186/ 1742-2094-7-99)

Wang HZ, Brown J \& Martin M 2011a Glycogen synthase kinase 3: a point of convergence for the host inflammatory response. Cytokine $\mathbf{5 3}$ 130-140. (doi:10.1016/j.cyto.2010.10.009)
Wang Q, Xu X, Li J, Liu J, Gu H, Zhang R, Chen J, Kuang Y, Fei J, Jiang C et al. $2011 b$ Lithium, an anti-psychotic drug, greatly enhances the generation of induced pluripotent stem cells. Cell Research 21 1424-1435. (doi:10.1038/cr.2011.108)

Weiss A, Goldman S \& Shalev E 2007 The matrix metalloproteinases (MMPS) in the decidua and fetal membranes. Frontiers in Bioscience 12 649-659. (doi:10.2741/2089)

Whittle BJ, Varga C, Posa A, Molnar A, Collin M \& Thiemermann C 2006 Reduction of experimental colitis in the rat by inhibitors of glycogen synthase kinase-3 $\beta$. British Journal of Pharmacology 147 575-582. (doi:10.1038/sj.bjp.0706509)

Woodgett JR 1990 Molecular cloning and expression of glycogen synthase kinase-3/factor A. EMBO Journal 9 2431-2438.

Yuskaitis CJ \& Jope RS 2009 Glycogen synthase kinase-3 regulates microglial migration, inflammation, and inflammation-induced neurotoxicity. Cellular Signalling 21 264-273. (doi:10.1016/j.cellsig. 2008.10.014)

Zhang P, Katz J \& Michalek SM 2009 Glycogen synthase kinase-3 $\beta$ (GSK3 $\beta$ ) inhibition suppresses the inflammatory response to Francisella infection and protects against tularemia in mice. Molecular Immunology 46 677-687. (doi:10.1016/j.molimm.2008.08.281)

Received 21 September 2014

First decision 20 October 2014

Revised manuscript received 10 November 2014

Accepted 2 December 2014 